\title{
Single-nucleotide polymorphisms: a perspective of cardiovascular prevention
}

\author{
Guilherme Brasil Grezzana ${ }^{1}$, José Luiz da Costa Vieira ${ }^{2}$, Vera Lúcia Portal ${ }^{3 *}$ \\ ${ }^{1} \mathrm{MSc}$ in Health Sciences (Cardiology) - Specialist in Cardiology, Instituto de Cardiologia do Rio Grande do Sul/Fundação Universitária de Cardiologia (IC-FUC), Porto Alegre, RS, Brazil \\ ${ }^{2} \mathrm{PhD}$ in Cardiology - Coordinator of the Medical Residency Outpatient Clinic, IC-FUC, Porto Alegre, RS, Brazil \\ ${ }^{3} \mathrm{PhD}$ in Health Sciences (Cardiology) - Vice-coordinator of the Graduate Program in Health Sciences at IC-FUC, Porto Alegre, RS, Brazil
}

Study conducted at Instituto de Cardiologia do Rio Grande do Sul/Fundação Universitária de Cardiologia (IC-FUC), Porto Alegre, RS, Brazi

Article received: $3 / 17 / 14$ Accepted for publication: 10/21/14

*Correspondence: Address: Av. Princesa Isabel, 370 Santana

Porto Alegre, RS - Brazil Postal code: $90620-000$

+55 51 3230-3600

veraportal.pesquisa@gmail.com

http://dx.doi.org/10.1590/1806-9282.61.05.458

Conflict of interest: none

\section{SUMMARY}

Introduction: several studies have evaluated the utilization of lipid biomarkers in an attempt to correlate them with clinical cardiovascular events. Nevertheless, the investigation of clinical conditions under specific plasmatic levels of lipoproteins for long periods presents limitations due to inherent difficulties that are related to the follow-up of individuals throughout their lives. Better understanding of the clinical response and occasional resistance to the action of hypolipidemic drugs in several clinic scenarios is also necessary.

Objectives: to determine the role of evaluation of single-nucleotide polymorphisms (SNPs) related to the metabolism of lipids, and its implications in different clinical scenarios.

Methods: a search of the literature in English and Spanish languages was performed in Medline, Lilacs via Bireme, IBECS via Bireme, and Cochrane databases. The expected results included information regarding plasmatic lipid profile and SNPs, cardiovascular clinical outcomes and polymorphisms related to the effectiveness of statins in the treatment of hypercholesterolemia.

Results: in order to perform this analysis, 19 studies were included from a total of 89 identified citations. The evaluation of the results suggests that low plasmatic levels of LDL-c are associated with a reduction in the risk of heart attacks, although this was not observed for the rise of plasmatic levels of HDL-c.

Conclusion: polymorphisms in different populations and clinical perspectives may bring important contributions for a better understanding and adequacy of plasmatic lipoproteins aiming at reducing cardiovascular risk.

Keywords: polymorphism, single nucleotide, dyslipidemias, hydroxymethylglutaryl-CoA reductase inhibitors.

\section{INTRODUCTION}

Hyperlipidemia is a major risk factor for developing coronary artery disease (CAD), and the leading cause of ischemic heart disease. ${ }^{1,2}$ Despite pharmacological advances and interventional treatments, morbidity and mortality of CAD remains high. ${ }^{3,2}$ Thus, the finding that low-density lipoprotein (LDL) and high-density lipoprotein (HDL) fractions are among the most requested biomarkers in clinical practice is justified. ${ }^{4}$ However, determining a causal role in the disease process and its pathophysiological marker cannot be done only based on observational studies. ${ }^{5}$

Several studies of primary and secondary prevention have shown a reduction of 25 to $35 \%$ in the risk of car- diovascular events through the use of individual statins ${ }^{6}$ despite inter variability in plasma lipid levels. This variation may be due to environmental factors such as body weight, smoking, diet and drugs, but also due to genetic polymorphisms involved in lipoprotein metabolism. ${ }^{4,7}$ The different responses to statins in reducing plasma lipid profile ${ }^{12}$ also play an important role in monitoring the dyslipidemic patient.

Thus, assessment of effect for a prolonged period of exposure to concentrations of lipoproteins may have a role in the risk considerations for $\mathrm{CAD}$ and for defining therapy. Therefore, evaluating lipoprotein subfractions as well as single nucleotide polymorphisms (SNPs) in 
genes involved in lipoprotein metabolism can clarify important aspects of the clinical monitoring of patients and correlations with cardiovascular outcomes. In this study, a systematic review of the literature aimed to evaluate the different SNPs and their correlations with the plasma lipid metabolism in various clinical settings, and populations studied was performed.

\section{Methods}

The present studies were found from the search of original articles, clinical trials, observational studies and case-control studies in the following electronic databases: Medline, Lilacs via Bireme, IBECS via Bireme and Cochrane. A search for articles of references was also performed manually.

The following MeSH terms for research in their different combinations were used: "Hypercholesterolemia", "Cholesterol, LDL", "Cholesterol, HDL", "Lipoproteins", "Dyslipidemias" and "Polymorphism, Single Nucleotide". The expected results included information related to various SNPs and their relationship with lipid profile and risk of cardiovascular events (Table 1). An independent researcher conducted the survey in the databases and then selected the relevant items, according to the inclusion and exclusion criteria.

- Inclusion criteria were: original studies from clinical trials, observational studies, cohort and case-control studies that investigated the influence of genotypic variations of SNPs and their relationship with lipid metabolism and cardiovascular risk.

- Exclusion criteria were: experimental studies, articles with polymorphisms unrelated to plasma lipid pro- file, studies with small sample size and study in languages other than English and Spanish.

\section{Results}

Out of 89 citations identified in the databases, 19 were eligible according to the criteria for inclusion in this systematic review (Figure 1). Of the total citations found, 16 were excluded for addressing experimental studies, two because they were written in Japanese, 4 due to the small size of samples and 48 studies for assessing polymorphism unrelated to the plasma lipid profile.

Nineteen studies were eligible and included in this review. The data from these studies are summarized in Tables 2 and 3.

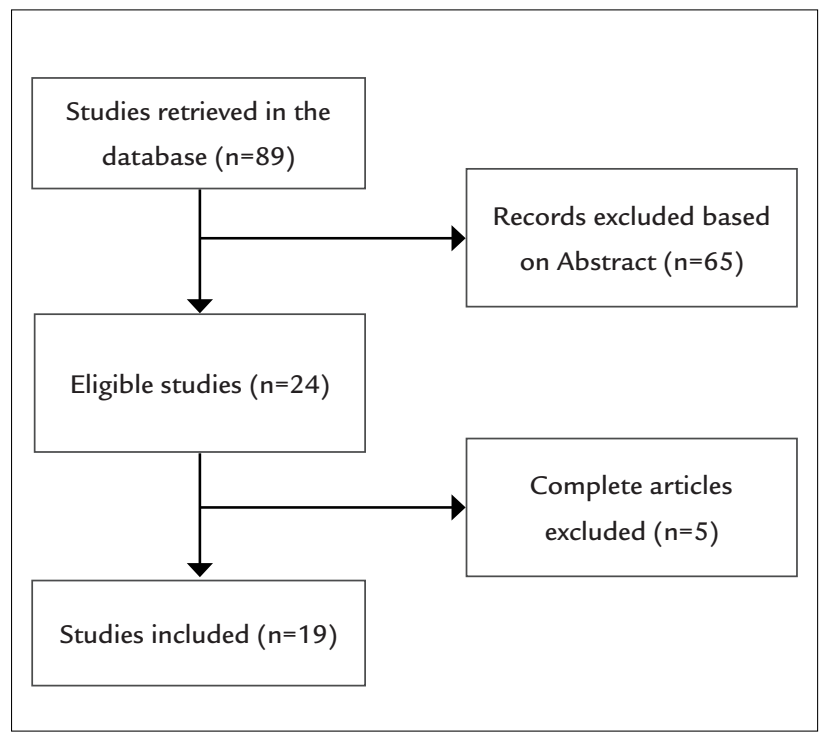

FIGURE 1 Flowchart of records retrieved and included.

\section{TABLE 1 Search in electronic databases performed on 10/28/2013.}

\begin{tabular}{|c|c|c|c|c|}
\hline Base & Terms & Results & $\begin{array}{l}\text { References } \\
\text { selected }\end{array}$ & $\begin{array}{l}\text { References } \\
\text { used }\end{array}$ \\
\hline $\begin{array}{l}\text { Lilacs via } \\
\text { Bireme }\end{array}$ & "Single nucleotide polymorphisms" & 25 & 2 & 1 \\
\hline $\begin{array}{l}\text { IBECS via } \\
\text { Bireme }\end{array}$ & "Single nucleotide polymorphisms" & 35 & 2 & 1 \\
\hline $\begin{array}{l}\text { Medline } \\
\text { via Bireme }\end{array}$ & $\begin{array}{l}\text { (((“"Hypercholesterolemia”[MeSH] AND “Cholesterol, LDL”[MeSH]) AND } \\
\text { "Cholesterol, HDL”[MeSH] AND “Lipoproteins”[MeSH]) AND “Dyslipid- } \\
\text { emias”[MeSH]) AND “Polymorphism, Single Nucleotide”[MeSH] }\end{array}$ & 14 & 10 & 10 \\
\hline $\begin{array}{l}\text { Cochrane } \\
\text { via Bireme }\end{array}$ & "Single nucleotide polymorphisms" & 13 & 7 & 4 \\
\hline $\begin{array}{l}\text { Manual } \\
\text { search }\end{array}$ & "Single nucleotide polymorphisms" & 2 & 2 & 2 \\
\hline Total & - & 89 & 23 & 19 \\
\hline
\end{tabular}




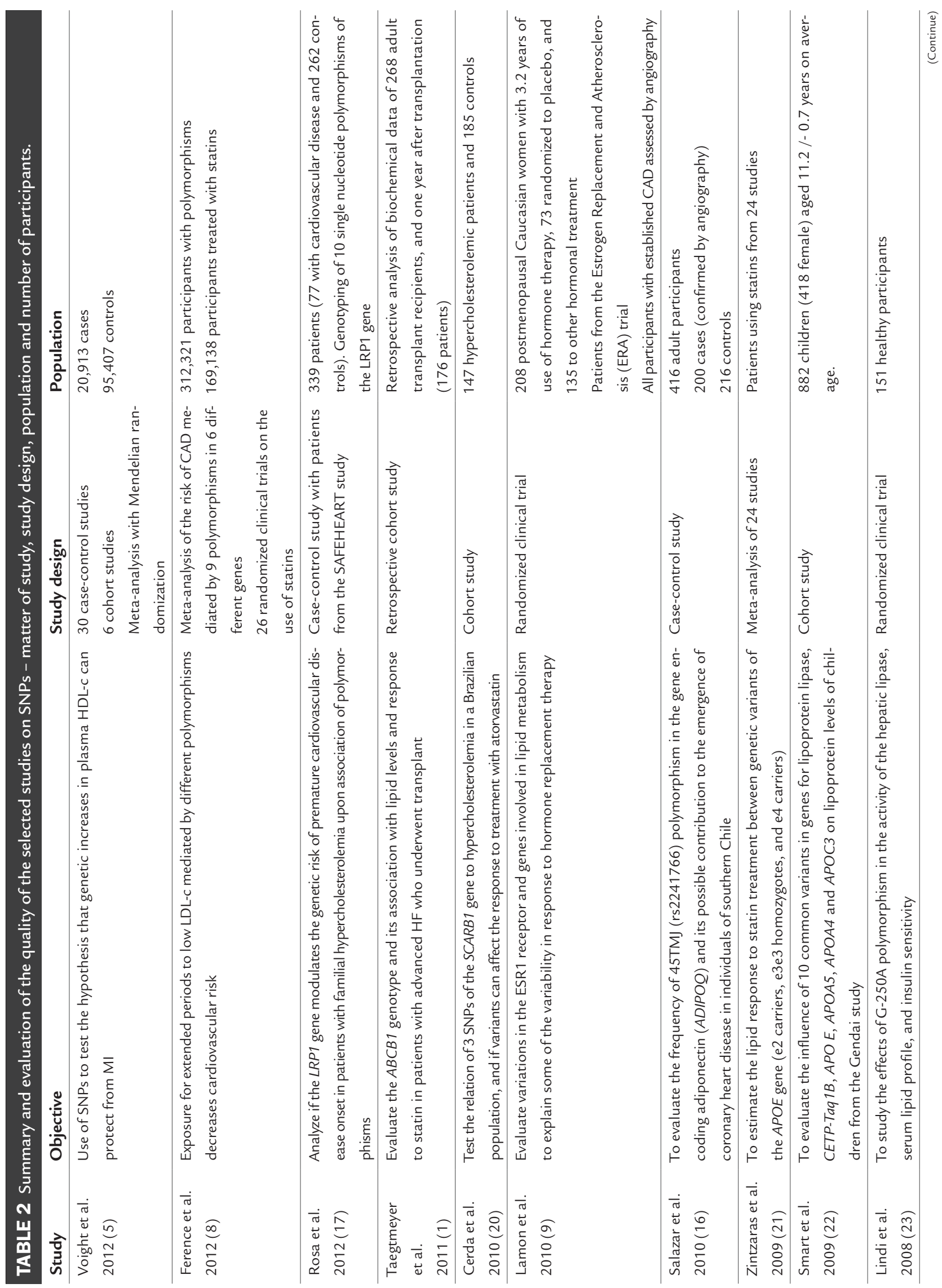




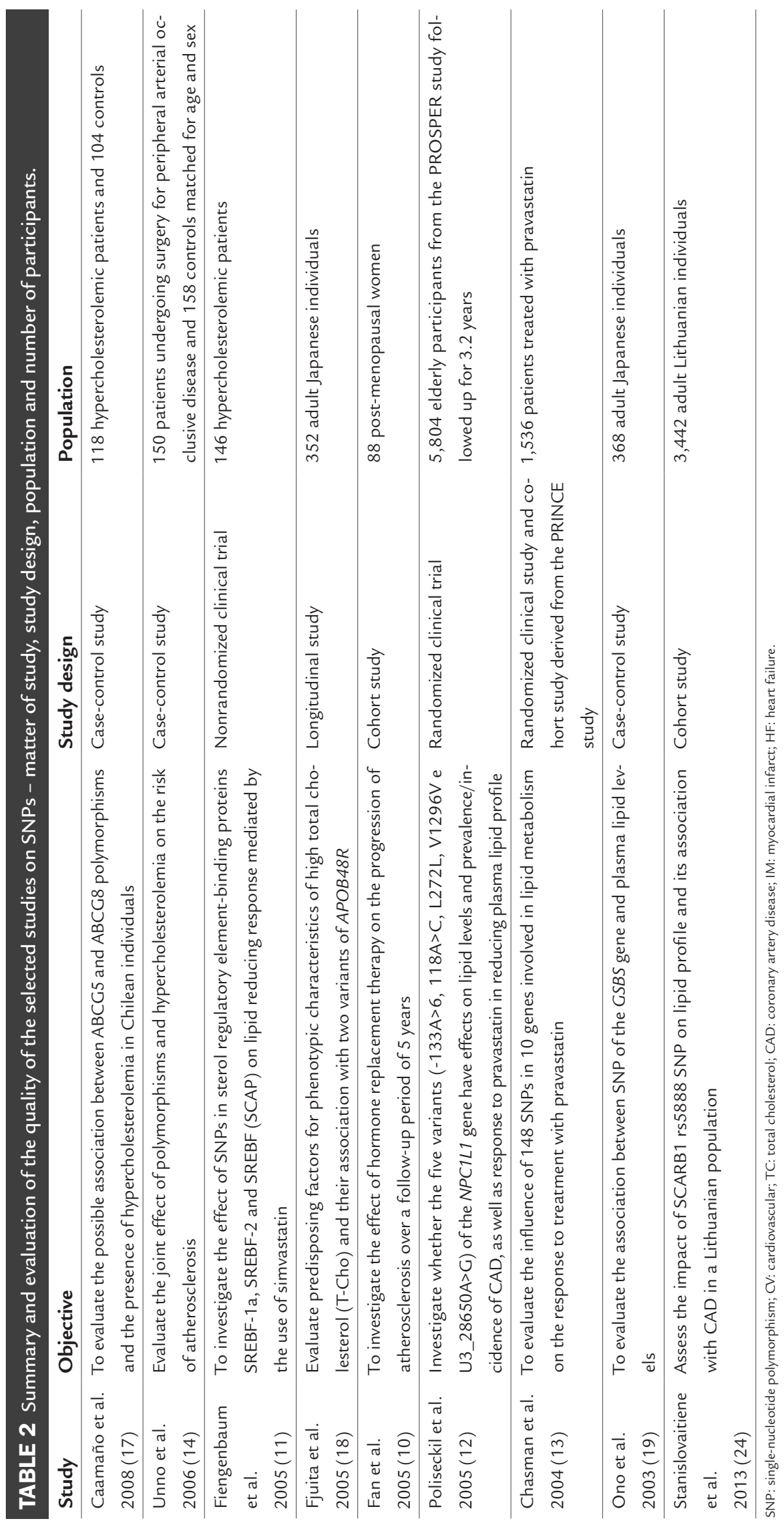



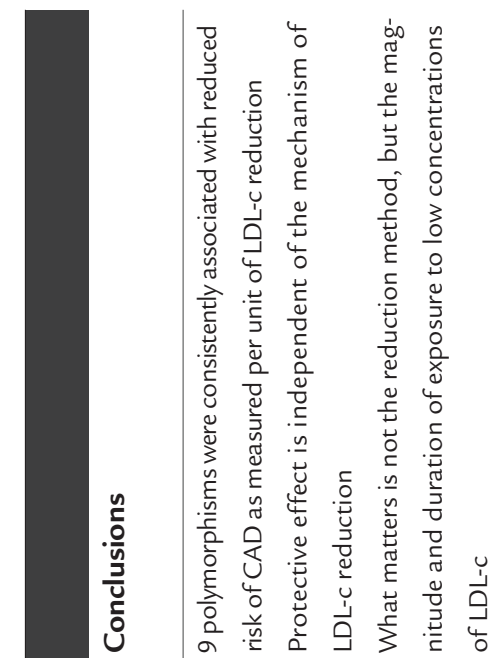

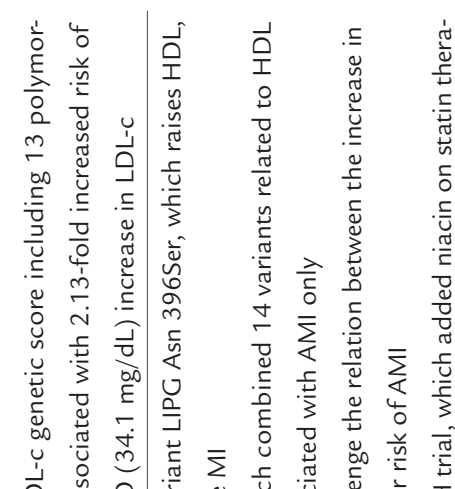

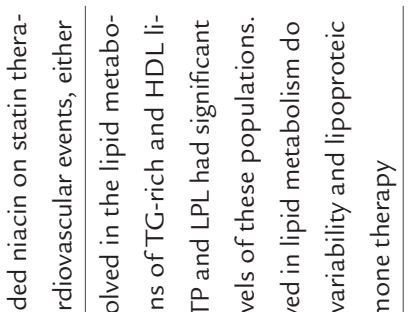

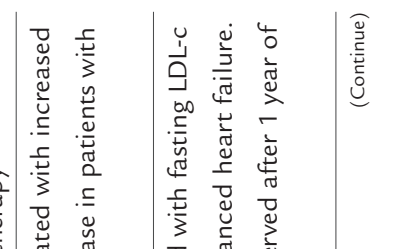
a

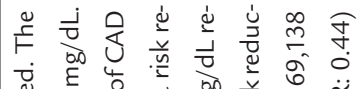

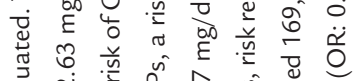 势}

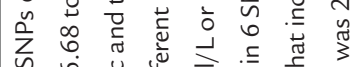
nิ

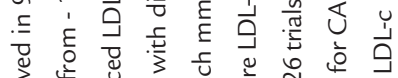

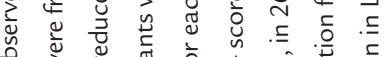

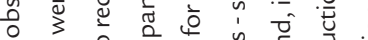

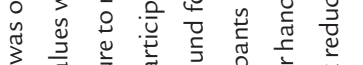
每 ণิ ชै

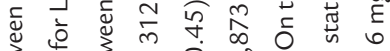
苋

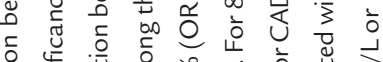

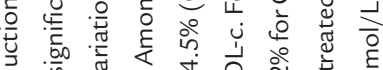
व

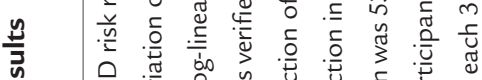

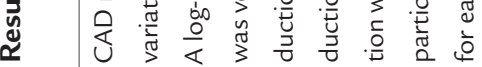

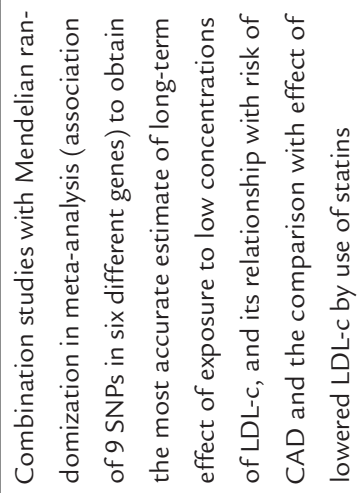

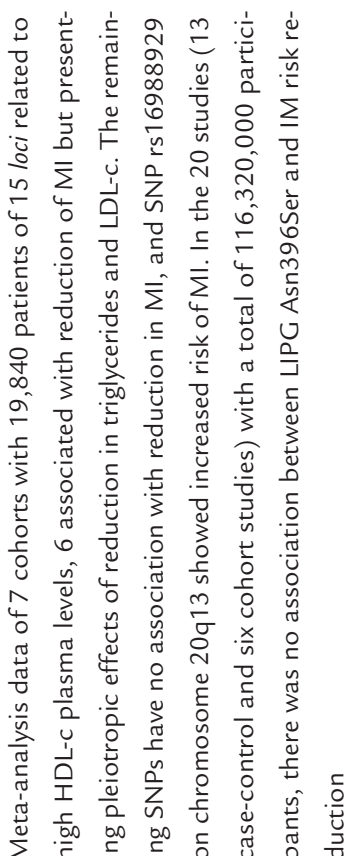

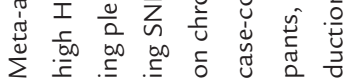

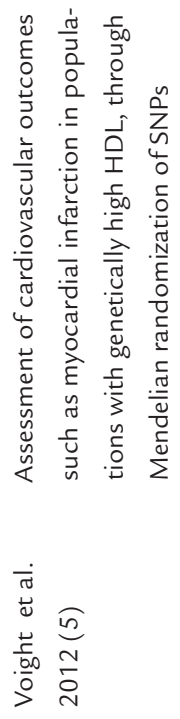

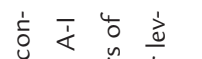

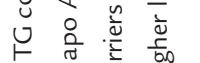

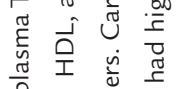

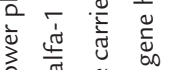

음

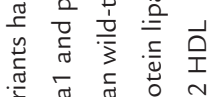

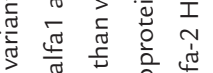

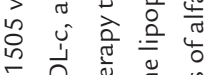

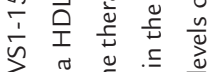

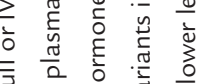

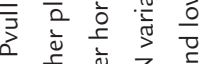

雨

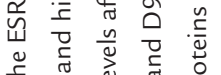

范

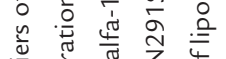

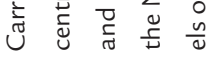

ช̊․ํำ

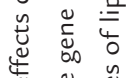

悹

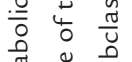

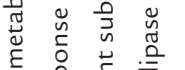

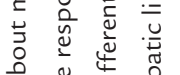

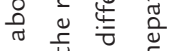

. 들 है

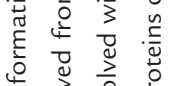

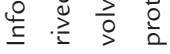

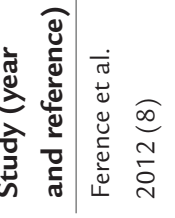

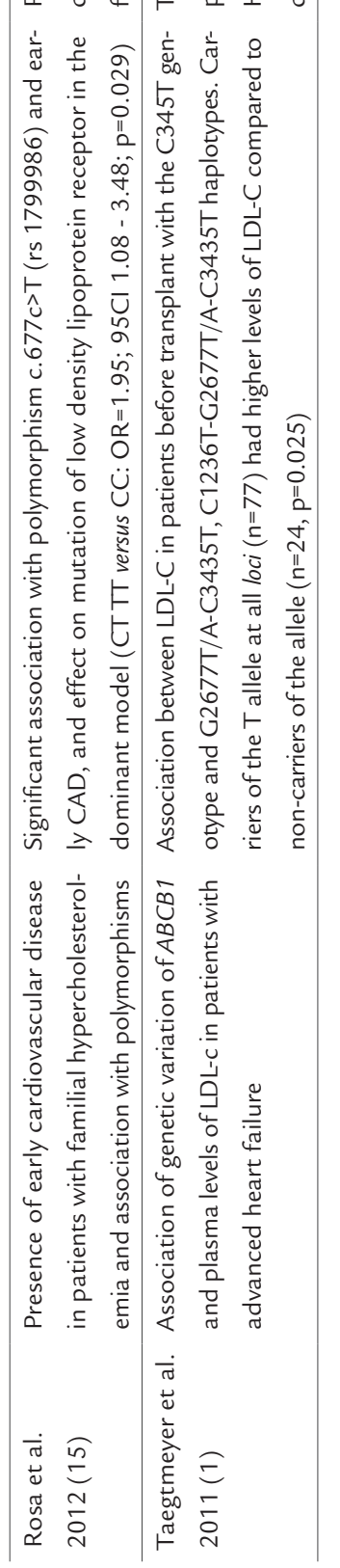




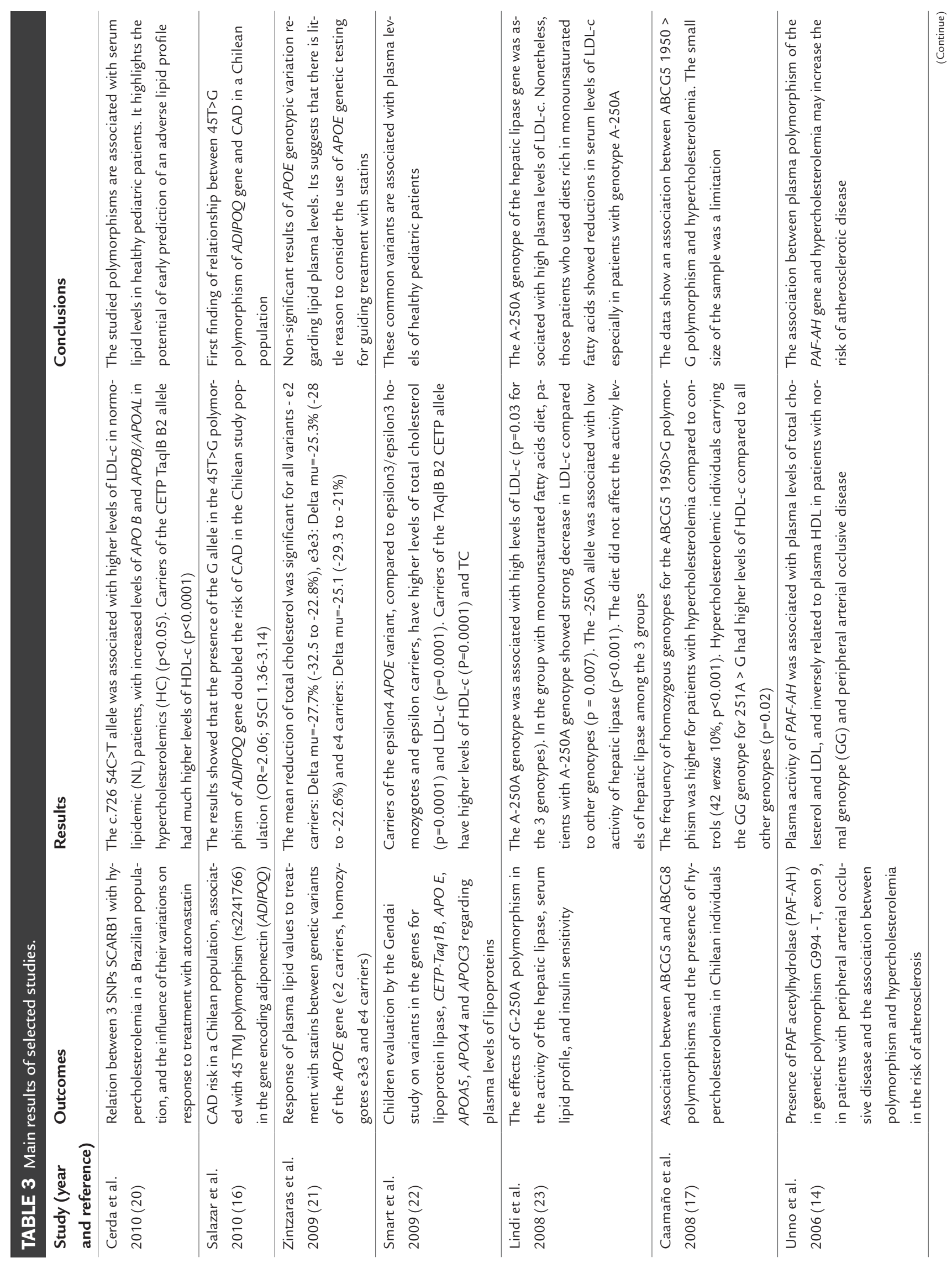




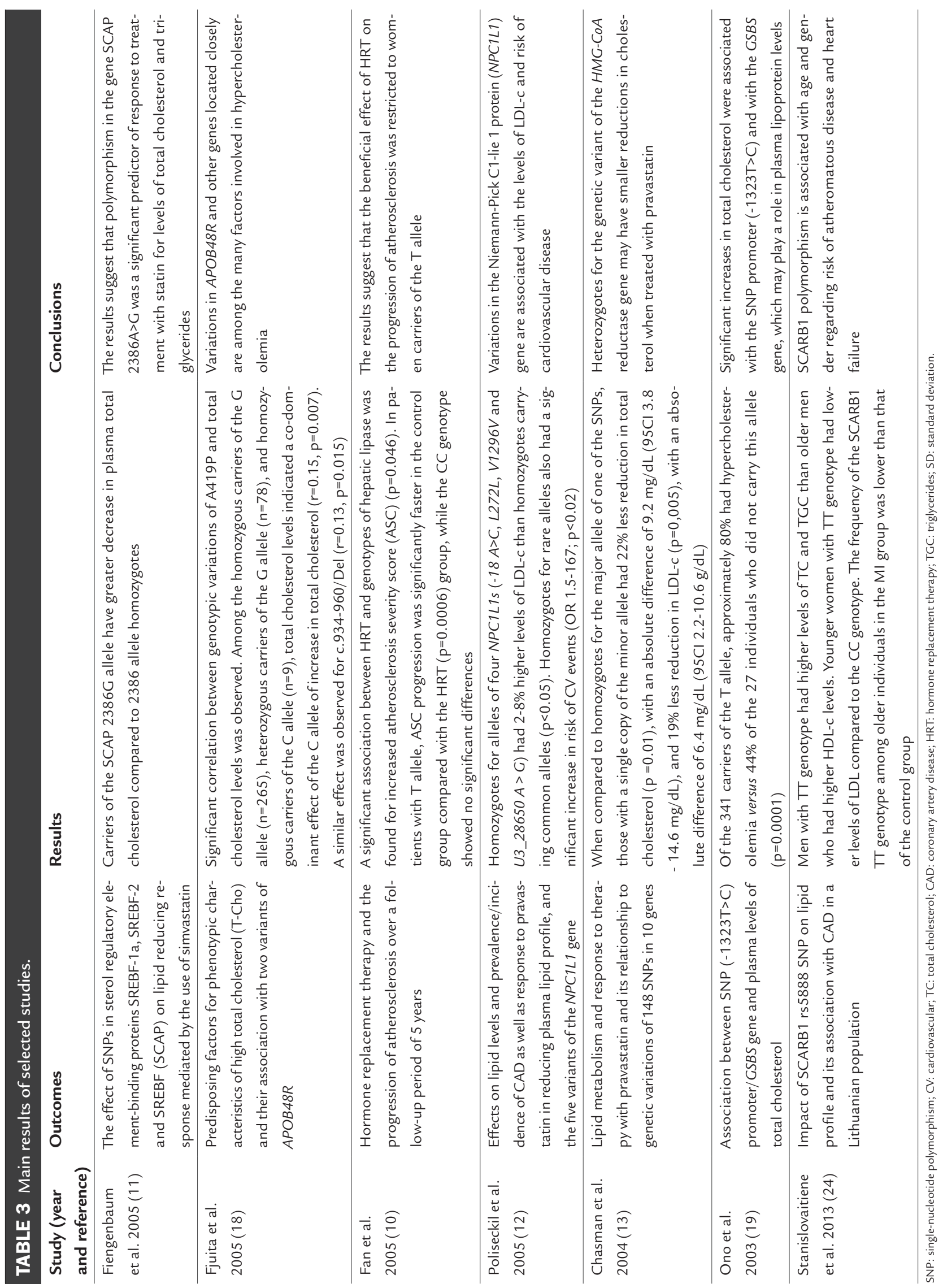




\section{Discussion}

Of the 89 studies identified for analysis, 19 were eligible for including relevant data to the plasma lipid profile and their relationship with several polymorphisms, thus allowing the analysis of data and results of interest. Among the selected studies, one used SNPs to test the hypothesis that genetic increases in HDL-cholesterol were associated with reduced risk of myocardial infarction (MI). Another study examined the exposure to LDL cholesterol in low plasma concentrations for extended periods of time against different polymorphisms and risk of cardiovascular disease (CVD). Nine studies tried to correlate premature CVD and hypercholesterolemia and their corresponding polymorphisms. Six studies assessed polymorphisms related to the therapeutic response to statins, and two studies were designed to correlate hormone replacement therapy (HRT) with polymorphisms and their lipid phenotype.

Two authors, Voight et al. ${ }^{5}$ and Ference et $a l,{ }^{8}$ conducted meta-analyzes using Mendelian randomization to assess prolonged action of high levels of HDL-c and low levels of LDL-c, respectively, and their association with the risk of cardiovascular outcomes. The study by Voight et al. ${ }^{5}$ aimed to evaluate high plasma levels of HDL-c through meta-analysis of 7 cohort studies with 19,840 patients. None of the 15 SNPs assessed correlated with risk of MI and, surprisingly, SNP rs16988929 was associated with increased risk of MI despite high levels of HDL-c. When this study assessed the genetic variant LIPG Asn 396Ser using meta-analysis of 20 studies with $116,320,000$ patients, the same result of no correlation was found for MI. These findings are relevant, because they cast doubt on interventions proposed until recently, from a clinical point of view, which are to increase HDL-c and use this biochemical marker as a substitute outcome in future studies. Similarly, a study by Ference et al. ${ }^{8}$ analyzed SNPs associated with lower plasma levels of LDL-c and their relation with cardiovascular outcomes through Mendelian randomization analysis, compared to the LDL-c reduction effects of statins. The main finding of this study was that all SNPs related with lower LDLc levels were also linked to lower risk of CAD. In this study, with a large number of participants, a relation between polymorphism profile and significant risk reduction for cardiovascular events was observed, with a reduction in risk between 54.5 and $53.2 \%$ for each $\mathrm{mmol} / \mathrm{L}$ decrease in LDL-c. However, in the analysis of 26 trials of studies using statins, there was a need to reduce the levels of LDL$\mathrm{c}$ three times more to achieve the same magnitude of CAD risk reduction. The study suggests that the effect of in- dependent protection of the LDL-c reduction mechanism and the method of reduction become less significant than the magnitude and time of exposure to low concentrations of LDL-c.

The study by Lamon et al. ${ }^{9}$ covers the effects of hormone replacement in women and their consequent lipid metabolic effects. In this study, SNPs in estrogen receptor alpha (ESR1), cholesterol ester transfer protein (CETP) and lipoprotein lipase (LPL) show significant baseline plasma effects of subpopulation with high levels of triglycerides (TGC) and HDL-c. However, polymorphisms of genes involved in lipid metabolism, with the exception of ESR1 SNPs, showed very modest effect on the lipoprotein variability in patients treated with hormone replacement. Hormone replacement therapy (HRT) and progression of atherosclerosis was also evaluated in a study by Fan et al. ${ }^{10}$ that evaluated 88 postmenopausal women with different genotypes of hepatic lipase. A significant association between HRT and genotypes of hepatic lipase was found for increased atherosclerosis severity score (ASC) measured by abdominal aorta and carotids ultrasound $(\mathrm{p}=0.046)$. In patients with $\mathrm{T}$ allele, ASC progression was significantly faster in the control group compared with the HRT ( $\mathrm{p}=0.0006)$ group, while the CC genotype showed no significant differences in ASC progression between controls and patients treated with HRT. Thus, the results suggest that the beneficial effect of HRT on atherosclerotic progression was restricted to women carriers of the $\mathrm{T}$ allele and not general, which contributes to the understanding of the role of HRT and its possible association with risk of atherosclerotic disease.

In a study to evaluate response to statin, Fiegenbaum et al. ${ }^{11}$ evaluated the effect of SNPs in sterol regulatory element-binding factors-1a (SREBF), SREBF-2 and SREBF cleavage activating protein (SCAP) on lipid reducing response mediated by the use of simvastatin. The results suggest that polymorphism in the gene SCAP 2386A>G was a significant predictor of response to treatment with statin for levels of total cholesterol and TGC. In the same line of study, Poliseckil et al. ${ }^{12}$ evaluated the effects on lipid levels and prevalence/incidence of CAD as well as response to pravastatin in reducing plasma lipid profile, and the five variants of the Niemann-Pick C1-lie 1 (NPC1L1) gene. The findings of the study indicate that variations in the NPC1L1 protein gene are associated with the levels of LDL-c and risk of cardiovascular disease. Also assessing efficacy reduction with the use of pravastatin in hypercholesterolemia, Chasman et al. ${ }^{13}$ examined the lipid profile and response to therapy with pravastatin, and its relation to genetic variations of 148 SNPs in 10 
genes. Knowing that 3-hydroxy-3-methylglutaryl (HMG)CoA reductase is the target enzyme that is inhibited by pravastatin, they observed that, compared to homozygotes for the larger allele of one of the SNPs, the ones that had a single copy of the minor allele had $22 \%$ less reduction in total cholesterol $(\mathrm{p}=0.01)$. Thus, heterozygotes for the genetic variant of the HMG-CoA reductase gene may have smaller reductions in cholesterol when treated with pravastatin. In another study, ${ }^{14}$ a significant association between hypercholesterolemia/risk of atherosclerosis and plasma $P A F-A H$ gene polymorphism in patients with peripheral arterial occlusive disease was observed.

In a study by Aledo et al., ${ }^{15}$ the development of early cardiovascular disease and mortality especially by CAD were assessed in patients heterozygotes for familial hypercholesterolemia (HFh). Genotyping for 10 polymorphisms of single nucleotide in the lipoprotein receptorrelated protein 1 (LRP1) gene was performed. The results showed an association between the $\mathrm{c} .677 \mathrm{C}>\mathrm{T}$ polymorphism and increased risk of premature cardiovascular disease in this population with familial hypercholesterolemia. Similarly, a study by Salazar et al. ${ }^{16}$ found correlation between 45 TMJ polymorphism in the adiponectin (ADI$P O Q)$ gene and $\mathrm{CAD}$ in a Chilean population. Another Chilean study conducted by Caamaño et al. ${ }^{17}$ found an association between ABCG5 $1950>G$ polymorphism and hypercholesterolemia in that specific population. Likewise, Fujita et al. ${ }^{18}$ found a significant correlation between the genotypes of A419P variants and the levels of total cholesterol. Their findings also indicate that variations in $A P O B 48 R$ and other genes located closely are among the many factors involved in hypercholesterolemia. In a study by Ono et al. ${ }^{19}$ significant increases in total cholesterol were associated with the SNP promoter $(-1323 T>C)$ and with the G-substrate (GSBS) gene, which may play a role in plasma lipoprotein levels.

The interaction between Apo A-l with the ATP binding receptors is part of the process of acquisition of free cholesterol in peripheral tissue. ${ }^{9}$ Variations in the $A B C B 1$ gene encoding P-glycoprotein (P-gp) are associated with lipid levels and response to statins. ${ }^{1}$ In cardiac transplant patients, the use of a triple immunosuppressive therapy ranges between $60-80 \%$, and hyperlipidemia is an important cardiovascular risk factor in these patients. ${ }^{1}$ In order to assess this relationship in patients with advanced heart failure, Taegtmeyer et al. ${ }^{1}$ confronted results of the genetic variation of $A B C B 1$ with plasma LDL-c levels in patients before and after cardiac transplantation. The authors observed an association between $A B C B 1$ haplotype and plasma levels of LDL-c prior to transplanta- tion; however, this correlation was not maintained when patients were reassessed one year after the completion of the transplant.

Assessing polymorphisms in a pediatric Brazilian population, evaluating three SNPs of SCARB1 gene and their relationship with hypercholesterolemia, as well as influence in response to treatment with atorvastatin was the objective of a study by Cerda et al. ${ }^{20}$ The study demonstrated the relationship between these polymorphisms and plasma lipid levels in healthy patients of this cohort and the importance of early assessment in order to identify unfavorable lipid profiles. Also, in a study by Zintzaras et al., ${ }^{21}$ the results were not significant regarding the relationship between the genetic variants of APOE and plasma lipid levels. However, in a study by Smart et al.,22 variants of genes of lipoprotein lipase, namely CETP-Taq1B, APO E, APOA5, APOA4 and $A P O C 3$, were associated with plasma levels of healthy pediatric populations.

In an interesting randomized clinical trial conducted by Lindi et al., ${ }^{23}$ the relationship between the effect of G-250A polymorphism and activity of the hepatic lipase, serum lipid profile, and insulin sensitivity was evaluated. A-250A genotype of the hepatic lipase gene was correlated with high levels of plasma LDL-c. Nonetheless, those patients who used diets rich in monounsaturated fatty acids showed reductions in serum levels of LDL-c especially in patients with genotype A-250A.

The evaluation of lipid phenotype regarding differences in the expression of SCARB1 rs5888 polymorphism, as conducted by Stanislovaitiene et al., ${ }^{24}$ showed differences in gender and age. Older men showed higher HDL levels while young women carriers of the TT genotype had lower LDL levels when compared to carriers of the C allele. The SACRB1 TT genotype was associated with less chance of coronary heart disease in men aged between 65 and 75 years.

\section{Conclusion}

Polymorphisms correlated with serum lipid metabolism, especially those associated with low plasma levels of LDL$c$ are associated with reduced risk of myocardial infarction. These findings do not extend to the increase in HDL$\mathrm{c}$ and its relationship to reduced risk of coronary artery disease. The evaluation of polymorphisms in different populations and clinical settings has a role in the future prospect of customized strategies for primary prevention of $\mathrm{CAD}$, according to the genetic inheritance of different polymorphisms that can increase the vulnerability of the patient. 


\section{Resumo}

Polimorfismos de nucleotídeo único: uma perspectiva de prevenção cardiovascular

Introdução: muitos estudos tem avaliado a utilização de biomarcadores lipídicos na tentativa de correlacioná-los com eventos clínicos cardiovasculares. Contudo, a investigação de condições clínicas sob níveis plasmáticos específicos de lipoproteínas por longos períodos, apresenta limitações devido às dificuldades inerentes relacionadas ao acompanhamento de indivíduos ao longo de suas vidas. Adicionalmente, há a necessidade de melhor compreensão da resposta clínica e eventual resistência da ação de drogas hipolipemiantes em diversos cenários clínicos.

Objetivos: determinar o papel da avaliação de polimorfismos de nucleotídeo único (SNPs) relacionadas com o metabolismo lipídico e suas implicações em diferentes cenários clínicos.

Métodos: foi realizada uma pesquisa na literatura de língua inglesa e espanhola nas bases de dados Medline, Lilacas via Bireme, IBECS via Bireme e Cochrane. Os resultados esperados incluíam informações sobre o perfil lipídico plasmático e SNPs, desfechos clínicos cardiovasculares e polimorfismos relacionadas à efetividade de estatinas quanto ao tratamento da hipercolesterolemia.

Resultados: para esta análise foram incluídos 19 estudos de um total de 89 citações identificadas. Os dados resultantes e avaliados sugerem que baixos níveis plasmáticos de LDL-c estão associados com redução do risco de infarto do miocárdio o que não foi observado para o aumento nos níveis plasmáticos de HDL-c.

Conclusões: os polimorfismos em diferentes populações e perspectivas clínicas podem trazer importantes contribuições para a melhor compreensão e adequação de metas de lipoproteínas plasmáticas que visem a redução de risco cardiovascular.

Palavras-chave: polimorfismo de nucleotídeo único, dislipidemias, inibidores de hidroximetilglutaril-CoA redutases.

\section{References}

1. Taegtmeyer AB, Breen JB, Smith J, Rogers P, Kullak-Ublick GA, Yacoub $\mathrm{MH}$, et al. Effect of $\mathrm{ABCB} 1$ genotype on pre- and post-cardiac transplantation plasma lipid concentrations. J Cardiovasc Transl Res. 2011;4(3):304-12
2. Mozaffarian D, Mussolino M, Nichol G, Roger VL, Rosamond W, Sacco R, et al. Executive summary: heart disease and stroke statistics--2010 update: a report from the American Heart Association. Circulation. 2010;121(7):948-54.

3. Tracking heart disease and stroke in Canada. Heart and Stroke Foundation of Canada; 2009. Available from: http://www.phac-aspc.gc.ca/publicat/2009/ cvd-avc/pdf/cvd-asv-2009-eng.pdf.

4. Expert Panel on Detection, Evaluation, and Treatment of High Blood Cholesterol in Adults. Executive Summary of The Third Report of The National Cholesterol Education Program (NCEP) Expert Panel on Detection, Evaluation, And Treatment of High Blood Cholesterol In Adults (Adult Treatment Panel III). JAMA. 2001;285(19):2486-97.

5. Voight BF, Peloso GM, Orho-Melander M, Frikke-Schmidt R, Barbalic M, Jensen MK, et al. Plasma HDL cholesterol and risk of myocardial infarction: a mendelian randomisation study. Lancet. 2012;380(9841):572-80.

6. Baigent C, Blackwell L, Emberson J, Holland LE, Reith C, Bhala N, et al. Efficacy and safety of more intensive lowering of LDL cholesterol: a metaanalysis of data from 170,000 participants in 26 randomised trials. Lancet. 2010;376(9753):1670-81

7. Sviridov D, Nestel PJ. Genetic factors affecting HDL levels, structure, metabolism and function. Curr Opin Lipidol. 2007;18(2):157-63.

8. Ference BA, Yoo W, Alesh I, Mahajan N, Mirowska KK, Mewada A, et al. Effect of long-term exposure to lower low-density lipoprotein cholesterol beginning early in life on the risk of coronary heart disease: a Mendelian randomization analysis. J Am Coll Cardiol. 2012; 60(25):2631-9.

9. Lamon-Fava S, Asztalos BF, Howard TD, Reboussin DM, Horvath KV Schaefer EJ, et al. Association of polymorphisms in genes involved in lipoprotein metabolism with plasma concentrations of remnant lipoproteins and HDL subpopulations before and after hormone therapy in postmenopausal women. Clin Endocrinol (Oxf). 72(2):169-75.

10. Fan YM., Dastidar P, Jokela H, Punnonen R, Lehtimäki T. Hepatic lipase $\mathrm{C}$-480T genotype-dependent benefit from long-term hormone replacement therapy for atherosclerosis progression in postmenopausal women. J Clin Endocrinol Metab. 90(6):3786-92.

11. Fiegenbaum M, Silveira FR, Van der Sand CR, Van der Sand LC, Ferreira ME, Pires RC, et al. Determinants of variable response to simvastatin treatment: the role of common variants of SCAP, SREBF-1a and SREBF-2 genes. Pharmacogenomics J. 2005;5(6):359-64.

12. Poliseckil E, Peter I, Simon JS, Hegele RA, Robertson M, Ford I, et al. Genetic variation at the NPC1L1 gene locus, plasma lipoproteins and heart disease risk in the elerly. J Lipid Res. 2010;51(5):1201-7.

13. Chasman DI, Posada D, Subrahmanyan L, Cook NR, Stanton VP Jr, Ridker PM. Pharmacogenetic study of statin therapy and cholesterol reduction. JAMA. 2004;291(23):2821-7.

14. Unno N, Sakaguchi T, Nakamura T, Yamamoto N, Sugatani J, Miwa M. et al. A single nucleotide polymorphism in the plasma PAF acetylhydrolase gene and risk of atherosclerosis in Japanese patients with peripheral artery occlusive disease. J Surg Res. 2006;134(1):36-43.

15. Aledo R, Alonso R, Mata P, Llorente-Cortés V, Padró T, Badimon L. LRP1 gene polymorphisms are associated with premature risk of cardiovascular disease in patients with familial hypercholesterolemia. Rev Esp Cardiol (Engl Ed). 2012;65(9):807-12.

16. Salazar LA, Colivoro K, Diaz A, Sepúlveda S, Cuevas A, Saavedra N, et al. Association between single nucleotide polymorphism of adiponectin gene and coronary artery disease in Southern Chilean subjects. Rev Chil Cardiol. 2010;29(2):214-20.

17. Caamaño JM, Pacheco A, Lanas F, Salazar LA. Single nucleotide polymorphisms in ABCG5 and ABCG8 genes in Chilean subjects with polygenic hypercholesterolemia and controls. Clin Chem Lab Med. 2008;46(11):1581-5.

18. Fujita Y, Ezura Y, Bujo H, Nakajima T, Takahashi K, Kamimura K, et al. Association of nucleotide variations in the apolipoprotein $\mathrm{B} 48$ receptor gene (APOB48R) with hypercholesterolemia. J Hum Genet. 2005;50(4):203-9.

19. Ono S, Ezura Y, Emi M, Fujita Y, Takada D, Sato K, et al. A promoter SNP $(-1323 \mathrm{~T}>\mathrm{C})$ in G-substrate gene (GSBS) correlates with hypercholesterolemia. J Hum Genet. 2003;48(9):447-50.

20. Cerda A, Genvigir FD, Arazi SS, Hirata MH, Dorea EL, Bernik MM, et al. Influence of SCARB1 polymorphisms on serum lipids of hypercholesterolemic individuals treated with atorvastatin. Clin Chim Acta. 2010;411(9-10):631-7. 
21. Zintzaras E, Kitsios GD, Triposkiadis F, Lau J, Raman G. APOE gene polymorphisms and response to statin therapy. Pharmacogenomics J. 2009;9(4):248-57.

22. Smart MC, Dedoussis G, Louizou E, Yannakoulia M, Drenos F, Papoutsakis $\mathrm{C}$, et al. APOE, CETP and LPL genes show strong association with lipid levels in Greek children. Nutr Metab Cardiovasc Dis 2010;20(1):26-33.

23. Lindi V, Schwab U, Louheranta A, Vessby B, Hermansen K, Tapsell L, et al. The G-250A polymorphism in the hepatic lipase gene promoter is associated with changes in hepatic lipase activity and LDL cholesterol: The KANWU Study. Nutr Metab Cardiovasc Dis 2008;18(2):88-95.

24. Stanislovaitiene D, Lesauskaite V, Zaliuniene D, Smalinskiene A, Gustiene $\mathrm{O}$, Zaliaduonyte-Peksiene $\mathrm{D}$, et al. SCARB1 single nucleotide polymorphism (rs5888) is associated with serum lipid profile and myocardial infarction in na age and gender-denpendent manner. Lipids in Health and Disease 2013;12:24. 